\title{
RESPONSE OF CONOCARPUS ERECTUS L. PLANTS GROWN ON SANDY SOIL TO HYDROGEL APPLICATION UNDER DEFICIT WATER CONDITIONS
}

\author{
M.E. Abd El Gayed ${ }^{(1)}$ and E.A. Moursi ${ }^{(2)}$ \\ (1) Botanical Gardens Res. Depart., Hort. Res. Instit. ARC. Giza, Egypt. \\ (2) Soils, Water and Environment Research Institute. ARC. Giza, Egypt. \\ Received: Sep. 18, 2019 \\ Accepted: Oct. 2, 2019
}

\begin{abstract}
Water deficit is a main factor of limiting the growth of plants, particularly in arid and semi-arid regions. So this study was conducted in order to assess the influence of applying hydrogel polymers to minimize the negative effects caused by deficit water. Hence, An experimental pots was carried out during 2017 and 2108 seasons at the nursery of Sakha Horticultural Research Station, Horticultural Research Institute, Agricultural Research Center to study the effect of tow irrigation intervals (4 and 8days) and four hydrogel rates $(0.0,0.2,0.4$ and $0.6 \% \mathrm{~g} / \mathrm{g})$ and their interactions on the growth traits and nutrition status of Conocarpus erectus $L$. plants as well as some soil properties were investigated. The obtained results point out that, growth parameters (plant height, number of shoots and leaves/plant and stem thickness, shoot fresh and dry weight and total green color) as well as the leaf mineral contents were significantly increased when buttonwood seedlings were watered every four days than when they were watered every eight days in both season. Conversely, leaf proline content was increased under irrigation every 8 days. in addition, adding hydrogel at 0.4 or 0.6 caused a significant increase in the previous growth aspects but decreased leaf proline content compared to the control. Both low irrigation period (4 days) or high of hydrogel rate $(0.6 \% \mathrm{w} / \mathrm{w})$ and their interaction gave the highest values of leaf total and free water contents as well as bound water and osmotic pressure were reduced. Finally, the largest rates of the hydrogel amendment (0.4 and 0.6\%) under irrigation every 4 or 8 days extended the loss of soil water, increased the plant ability reflected in the accessible soil water and thus enhanced the growth parameters of the seedlings.
\end{abstract}

Key words: Water absorbing soil amendments, Conocarpus erectus L. plants, growth, water saving

\section{INTRODUCTION}

Conocarpus erectus L. is a multitrunked, evergreen plant (1-4 $\mathrm{m}$ high) that can grow into a tree up to $20 \mathrm{~m}$. It belongs to the family of Combretaceae and is frequently referred to as buttonwood and grows in tropical and subtropical districts. The root system consists of lateral and fine roots. The bark is fibrous and moderately thin. The leaves are spirally arranged, somewhat fleshy, with petioles. Inflorescences are terminal and small flowers in spheroidal heads are grouped. The bark and leaves have been used in tannery. Its timber is commonly used for high-grade charcoal and housing. (Al-Humaid and Moftah, 2007 and Hegazy et al., 2008).

Due to the growing demand for wood products and bio-energy biomass, efforts are presently being made to boost the output of timber throughout the globe. New desert lands are areas that may be accessible for this purpose, where water shortages are generally the limiting factor for planting. 
Under climatic changes and water resource limitations facing Egypt, we should do our best to efficiently renationalize orchard-level irrigation water. Water is one of the most critical crop production factors in Egypt. Rainfall is small, so most agricultural output depends on irrigation for the most part. Water resources on the Nile River are restricted and focused (El-Kady and Borham, 2013).

Minimizing water losses can be implemented with soil modifications that enhance the physical characteristics of the soil and boost the effectiveness of water irrigation and rationalization of water irrigation (Esteban et al., 2011). One of the latest soil modifications applied in this regard is the use of watersaving modifications, i.e. hydrogel polymers to enhance water and nutrient effectiveness, which become more essential over time, especially in arid and semi-arid areas with limited water sources. Under water circumstances, soil water and nutrients stored in hydrogel are gradually released for plant growth (Yazdani et al., 2007). Hydrogel is sometimes referred to as "Root watering crystals" or "water retention granules" because it swells like sponges to be as many times the initial size when it comes into contact with water, thus increasing the ability of soil water retention and decreasing irrigation frequency (Huttermann et al., 1999, Ghasemi and Khoshkhoe, 2007). The primary objectives of this research were therefore to explore the impact of irrigation intervals at distinct hydrogel rates on the growth of Conocarpus erectus L. seedling as well as soil properties in the form of a pot experimental research.

\section{MATERIALS AND METHODS Experimental site and plant material}

During the 2017 and 2018 seasons, an experimental pot was conducted in the nursery of Sakha Horticultural Research Station, Horticultural Research Institute, Agricultural Research Center, North Middle Nile Delta, Egypt $\left(31^{\circ} 77^{\prime} \mathrm{N}\right.$ latitude and $30^{\circ} 57^{\prime} \mathrm{E}$ longitude at an altitude of approximately 6 meters above sea level) to study the effect of hydrogel rates and on the growth of Conocarpus erectus $\mathrm{L}$. under irrigation intervals. The study period meteorological information were provided in Table 1.

Table (1): Average of the monthly meteorological data during the two growing seasons.

\begin{tabular}{ccccccc}
\hline Month & \multicolumn{2}{c}{$\mathrm{T}\left(\mathrm{C}^{\circ}\right)^{\star}$} & \multicolumn{2}{c}{$\mathrm{RH} \%$} & $\mathrm{~W}$ & Pan Evap. \\
\cline { 2 - 5 } & Max & Min & Max & Min & m/sec & mm/day \\
April. & 27.2 & 20.8 & 80.2 & 47.4 & 81.7 & 497.7 \\
May & 30.9 & 24.8 & 76.7 & 44.8 & 101.2 & 646.5 \\
June & 32.6 & 26.7 & 77.8 & 49.7 & 100.5 & 740.2 \\
July & 34.2 & 27.2 & 83.5 & 54.3 & 58.2 & 690.6 \\
Agus. & 33.9 & 26.8 & 84.2 & 43.4 & 73.1 & 623 \\
Sep. & 32.7 & 24.7 & 84.7 & 49.3 & 77.2 & 517.3 \\
Oct. & 29.1 & 22.3 & 81.8 & 52.2 & 65.6 & 325.2 \\
\hline
\end{tabular}

T: temperatures, $\mathrm{RH}$ : relative humidity, Ws: wind speed

*Source: Meteorological Station at Sakha, Kafr EL-Sheikh Governorate. 
Conocarpus erectus $\mathrm{L}$. seedlings were obtained from a commercial nursery and transplanted to plastic pots $(30 \times 21 \mathrm{~cm}$ about $6 \mathrm{~kg} / \mathrm{pot}$ ) filled with a washed sand. On the second week of April in both seasons (beginning of the study), healthy seedlings of uniformly height were selected (average height was $20 \pm 5 \mathrm{~cm}$ ). The soil mixture was then prepared from the previous washed sand and hydrogel in dry form.

\section{Experimental soil analysis}

The physical and chemical properties as well as soil moisture content of the soil used before beginning the experimental were determined according to Jackson (1967) and Black et al. (1965) and are given in Table (2). Pots were immediately watered after placing the hydrogel levels. All seedlings were fertilized according to recommendation rates with NPK (1:1:1) at $20 \mathrm{~g} /$ pot.

\section{Experimental design and} treatments:

Seventy two uniform seedlings were selected and arranged in a factorial randomized complete block design. The combinations between the two factors; the irrigation intervals (A) and the hydrogel rates (B) in addition to their interactions resulting eight treatments (2 irrigation intervals $x 4$ rates of hydrogel ) each treatment were replicated three times with three seedlings for each replicate (3 replicates $\times 3$ seedlings). as follow:

I. Factor A was assigned in two irrigation intervals as, irrigation every 4 and 8 days

The quantity of irrigation water applied (I/plant/year) and number of irrigations in the different irrigation treatments during each growing season were showed in Table (3).

II. Factor B was aranged for four soil applications of hydrogel at rates of 0.0 as control, $0.2,0.4$ and $0.6 \%$ $(\mathrm{g} / \mathrm{g})$

Hydrogel polymer known "Aquagool" $(40 \%$ Hydro polymer, $6.5 \% \mathrm{~N}, 4.8 \% \mathrm{P}$, $8.2 \% \mathrm{~K}$ and hold capacity at $300-500 \%$ ) produced by Lucky Star TG., Egypt

Table (2): Some chemical, physical properties and soil moisture constant of the soil used.

\begin{tabular}{|c|c|c|c|c|c|c|c|c|c|}
\hline \multirow{2}{*}{$\begin{array}{c}E c \\
\left(\mathrm{dSm}^{-1}\right)\end{array}$} & \multirow[t]{2}{*}{ O.M (\%) } & \multirow[t]{2}{*}{$\mathrm{pH}$} & \multicolumn{3}{|c|}{ Soluble catine (meq/l) } & \multicolumn{4}{|c|}{ Soluble anions (meq/l) } \\
\hline & & & $\mathrm{Ca}^{++}$ & $\mathbf{M g}^{++}$ & $\mathrm{K}^{+}$ & $\mathrm{Na}^{+}$ & $\mathrm{SO}_{4}^{--}$ & $\mathrm{HCO}_{3}^{-}$ & $\mathrm{Cl}^{-}$ \\
\hline 2.03 & 0.06 & 7.80 & 5.7 & 3.5 & 0.2 & 10.9 & 6.7 & 5.3 & 8.3 \\
\hline \multicolumn{3}{|c|}{ Particle size divisions (\%) } & \multirow{2}{*}{$\begin{array}{c}\text { Textural } \\
\text { class }\end{array}$} & \multicolumn{6}{|c|}{ Soil moisture properties (\%) } \\
\hline Sand & Silt & Clay & & FC $^{*}$ & WP* & \multicolumn{2}{|c|}{ 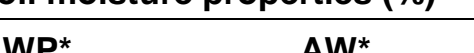 } & & \\
\hline 98.2 & 1 & 0.8 & Sandy & 8.4 & 2.8 & & & & \\
\hline \multicolumn{10}{|c|}{${ }^{*}=$ FC: Field capacity, WP: wilting point, AW: available water } \\
\hline \multicolumn{10}{|c|}{$\begin{array}{l}\text { Table (3): The quantity of irrigation water applied (I/plant/y.) and number of irrigations in } \\
\text { the different irrigation treatments (average of two seasons). }\end{array}$} \\
\hline \multicolumn{3}{|c|}{ Irrigation intervals } & \multicolumn{3}{|c|}{ Number of irrigations } & & \multicolumn{3}{|c|}{$\begin{array}{l}\text { Water applied } \\
\text { (1/plant/season) }\end{array}$} \\
\hline \multicolumn{3}{|l|}{4 days } & \multicolumn{3}{|c|}{46} & \multicolumn{4}{|c|}{46} \\
\hline \multicolumn{3}{|l|}{8 days } & \multicolumn{3}{|c|}{23} & \multicolumn{4}{|c|}{23} \\
\hline
\end{tabular}


The following data were recorded: 1-Vegetative growth traits:

On $20^{\text {th }}$ and $25^{\text {th }}$ October in 2017 and 2018 seasons, respectively, after 6 months of planting, eight plants per treatment were randomly sampled. Plant height and root length $(\mathrm{cm})$ were measured, also number of shoots and leaves /plant were counted. As well as chlorophyll index (total green color) was estimate according to Yadava (1986) by using chlorophyll meter (A Minolta SPAD). Afterwards, seedlings were cut at the cotyledon insertion point and separated into shoots (main stem+ branches+ leaves) and roots., in addition to determining shoots and roots fresh and dry weights (g). Roots fresh samples were carefully thoroughly washed with tap water in order to get rid of the remaining soil mixture then dried on filter papers and immediately weighed. The seedling parts dry weights were determined by drying samples at $70{ }^{\circ} \mathrm{C}$ to a constant weight for approximately $48 \mathrm{hr}$. The shoot: root ratio $(\mathrm{g} / \mathrm{g})$ was calculated from the obtained dry weights.

\section{2-Nutritional status: \\ Leaf mineral content:}

At the end of November 20 mature leaves/ plant were sampled in both seasons, washed, dried at $70^{\circ} \mathrm{C}$ to a constant weight ground and digested for determination leaf mineral content. Nitrogen was determined by Microkjeldahl method as outlined by Chapman and Pratt (1978). Phosphorus was determined using spectrophotometer according to Murphy and Riely (1962). Potassium determined by flame photometer according to Jackson (1967).

Leaf proline content ( $\mu$ mole/g). was determined conferring to Bates et al., (1973).

\section{3-Water Relation:}

Total and free water contents in leaf tissues, also bound water content and osmotic of the cell sap of leaves were determined according to the method described by Koshirinko et al. (1970).

\section{4- Soil properties}

Physical characteristics of the studied soil such as soil field capacity (FC), permanent wilting point (PWP) and available water were determined according to Klute (1986)

\section{Statistical analysis}

Data were analyzed by MSTATC computer software program (Bricker, 1991). The obtained data were subjected to analysis of variance according Snedecor and Cochran (1990). Duncan's multiple range test (Duncan, 1955) at $5 \%$ level was used to compare the means.

\section{RESULTS AND DISCUSSION}

1- Vegetative growth parameters:

Data presented in Tables (4 and 5) show the impacts of irrigation intervals, hydrogel rates and their interaction on buttonwood seedlings growth characteristics during the 2017 and 2018 seasons. By reducing irrigation intervals and increasing hydrogel rates relative to control, growth characteristics were generally enhanced.

\section{a. Plant height, number of shoots and leaves/plant and stem thickness}

Results presented in Table (4) showed that plant height, number of shoots and leaves/plant and stem thickness were significantly increased when buttonwood seedlings were watered every four days than when they were watered every eight days in both season. The reduction in vegetative growth under watering every 8 days (watering regime) could be attributed to minimal availability of assimilation by decreasing net 
photosynthesis under water stress (Mpelascoka et al., 2001) In addition, drought stress prompted the development of abcisic acid (ABA) in the root and vegetative parts and enhanced consistency of reactive oxygen species (ROS) to reduce vegetative growth. (Atkinson et al., 2000). These results agree with the findings of El-Kady and Borham (2013) on buttonwood plants and Kargar et al., (2017) on silver maple, who indicated that, under water deficit, the values of vegetative growth parameters were significantly decreased. Seedlings grown in soil amended with hydrogel exhibited higher values of former mentioned growth parameters than those grown in soil without hydrogel. The highest values were obtained from soil amended with $0.6 \%(\mathrm{~g} / \mathrm{g})$ hydrogel more than the other rates in both seasons. The increment in vegetative growth parameters due to hydrogel applications may be due to improvement of water holding capacity and physical properties of the soil, better absorption of irrigation water and its storage in the soil and so, prevent the moisture stresses which reflected on vegetative growth (Sheikh et al., 2010). In addition, Andry et al., (2009) confirmed the effects of superabsorbent polymers in density and growth of the root due to improvement in physical condition of the soil. This growth increase is caused by indirect role of amendment materials increase $\mathbf{N}, \mathrm{P}$ and $\mathrm{k}$ uptake by the plant, appropriate aeration and available water by increasing the water holding capacity of the soil which reduce water stress of plants resulting in increased growth and plant performance. However. Al-Humaid and Moftah (2007), Orikiriza et al., (2009) and Hassan et al., (2017), reported that incorporation of hydrogel in sandy soil significantly increased the growth parameters.

Table (4): Effect of irrigation intervals, hydrogel rates and their interaction on plant height, No. of shoots and leaves/plant and stem thickness of Conocarpus erectus L. plants in 2017 and 2018 seasons.

\begin{tabular}{|c|c|c|c|c|c|c|c|c|c|}
\hline \multirow{2}{*}{\multicolumn{2}{|c|}{ Treatments }} & \multicolumn{2}{|c|}{$\begin{array}{l}\text { Plant height } \\
\text { (cm) }\end{array}$} & \multicolumn{2}{|c|}{$\begin{array}{c}\text { No. of } \\
\text { Shoots/plant }\end{array}$} & \multicolumn{2}{|c|}{$\begin{array}{c}\text { No. of } \\
\text { leaves/plant }\end{array}$} & \multicolumn{2}{|c|}{$\begin{array}{c}\text { Stem } \\
\text { thickness }(\mathrm{cm})\end{array}$} \\
\hline & & 2017 & 2018 & 2017 & 2018 & 2017 & 2018 & 2017 & 2018 \\
\hline \multicolumn{10}{|c|}{ Irrigation intervals } \\
\hline & 4 days & $71.25 a$ & $72.92 a$ & $27.67 a$ & 28.17a & $399.4 a$ & $395.8 \mathrm{a}$ & $1.18 \mathrm{a}$ & $1.16 a$ \\
\hline & 8 days & $66.58 b$ & $68.58 b$ & $23.75 b$ & $24.75 b$ & $338.8 b$ & $341.9 b$ & $1.01 \mathrm{a}$ & $1.01 b$ \\
\hline \multicolumn{10}{|c|}{ Hydrogel rates (\%) } \\
\hline & 0 (Cont.) & $61.50 \mathrm{~d}$ & $63.17 d$ & 19.83de & 20.83d & 297.2d & $304.2 d$ & $0.92 d$ & $0.92 c$ \\
\hline & 0.2 & $66.17 \mathrm{c}$ & $68.83 \mathrm{c}$ & $24.50 c$ & $25.00 \mathrm{c}$ & $352.3 \mathrm{c}$ & $349.0 \mathrm{c}$ & $1.07 \mathrm{c}$ & $1.00 \mathrm{c}$ \\
\hline & 0.4 & $70.00 \mathrm{~b}$ & $72.00 \mathrm{~b}$ & $27.50 \mathrm{~b}$ & $28.50 \mathrm{~b}$ & $400.0 \mathrm{~b}$ & $395.8 b$ & $1.15 b$ & $1.13 b$ \\
\hline & 0.6 & $78.00 \mathrm{a}$ & $79.00 \mathrm{a}$ & $31.00 a$ & $31.50 \mathrm{a}$ & $426.8 a$ & $426.3 a$ & $1.25 \mathrm{a}$ & $1.28 \mathrm{a}$ \\
\hline \multicolumn{10}{|c|}{ Interaction (I x H) } \\
\hline & 0.00 (Cont.) & $65.00 \mathrm{~d}$ & $66.33 e$ & 22.33d & 23.67d & $319.7 e$ & $325.3 e$ & $1.03 \mathrm{de}$ & $1.00 \mathrm{cde}$ \\
\hline \multirow{4}{*}{$\begin{array}{c}4 \\
\text { days }\end{array}$} & 0.2 & $69.00 \mathrm{c}$ & $71.00 \mathrm{c}$ & $27.00 \mathrm{c}$ & $26.67 \mathrm{c}$ & $403.3 c$ & $394.7 \mathrm{c}$ & $1.13 b c$ & $1.10 \mathrm{bc}$ \\
\hline & 0.4 & $71.00 \mathrm{c}$ & $73.67 \mathrm{bc}$ & $29.00 \mathrm{~b}$ & $29.67 b$ & $424.3 b$ & $411.7 \mathrm{~b}$ & $1.20 \mathrm{~b}$ & $1.20 \mathrm{ab}$ \\
\hline & 0.6 & $80.00 a$ & $80.67 a$ & $32.33 a$ & $32.67 a$ & $450.3 a$ & $451.3 a$ & $1.37 a$ & $1.33 a$ \\
\hline & 0.00 (Cont.) & $58.00 \mathrm{e}$ & $60.00 f$ & $17.33 \mathrm{e}$ & $18.00 \mathrm{e}$ & $274.7 \mathrm{~g}$ & $283.0 \mathrm{~g}$ & $0.80 f$ & $0.83 e$ \\
\hline \multirow{3}{*}{$\begin{array}{c}8 \\
\text { days }\end{array}$} & 0.2 & $63.33 d$ & 66.67de & $22.00 \mathrm{~d}$ & 23.33d & $301.3 f$ & $303.3 f$ & $1.00 \mathrm{e}$ & $0.90 \mathrm{be}$ \\
\hline & 0.4 & $69.00 \mathrm{c}$ & $70.33 \mathrm{~cd}$ & $26.00 \mathrm{c}$ & $27.33 \mathrm{c}$ & $375.7 d$ & $380.0 \mathrm{~d}$ & $1.10 \mathrm{~cd}$ & $1.07 \mathrm{bcd}$ \\
\hline & 0.6 & $76.00 \mathrm{~b}$ & 77.33ab & $29.67 b$ & $30.33 b$ & $403.3 \mathrm{c}$ & $401.3 \mathrm{c}$ & $1.13 b c$ & $1.23 \mathrm{ab}$ \\
\hline
\end{tabular}

Means within a column having the same letters are not significantly differences according to Duncan's multiple range test (DMRT). 
Table (5): Effect of irrigation intervals, hydrogel rates and their interaction on shoot fresh and dry weight, root length and total green color of Conocarpus erectus $\mathrm{L}$. plants in 2017 and 2018 seasons.

\begin{tabular}{|c|c|c|c|c|c|c|c|c|}
\hline \multirow[t]{2}{*}{ Treatments } & \multicolumn{2}{|c|}{$\begin{array}{l}\text { Shoot fresh } \\
\text { weight }(\mathrm{g})\end{array}$} & \multicolumn{2}{|c|}{$\begin{array}{l}\text { Shoot dry } \\
\text { weight (g) }\end{array}$} & \multicolumn{2}{|c|}{$\begin{array}{l}\text { Root length } \\
\text { (cm) }\end{array}$} & \multicolumn{2}{|c|}{$\begin{array}{c}\text { Total green color } \\
\text { (SPAD) }\end{array}$} \\
\hline & 2017 & 2018 & 2017 & 2018 & 2017 & 2018 & 2017 & 2018 \\
\hline \multicolumn{9}{|l|}{ Irrigation intervals } \\
\hline 4 days & $116.02 a$ & $115.8 \mathrm{a}$ & $37.62 a$ & $37.07 a$ & $43.08 a$ & $42.67 a$ & $109.17 a$ & $82.48 a$ \\
\hline 8 days & $88.05 b$ & $74.08 b$ & $29.70 b$ & $24.78 b$ & $38.75 b$ & $40.33 b$ & $90.00 \mathrm{~b}$ & $66.62 b$ \\
\hline \multicolumn{9}{|l|}{ Hydrogel rates (\%) } \\
\hline 0.00 (Cont.) & $75.87 b$ & $67.87 d$ & $26.03 b$ & $23.37 d$ & $36.50 \mathrm{c}$ & $38.33 c$ & $89.20 d$ & $59.65 \mathrm{c}$ \\
\hline 0.2 & $86.20 c$ & $84.52 \mathrm{c}$ & 29.37c & $28.67 \mathrm{c}$ & $40.50 \mathrm{~b}$ & $41.50 \mathrm{~b}$ & $94.60 \mathrm{c}$ & $73.63 b$ \\
\hline 0.4 & $109.08 b$ & $100.32 b$ & $37.68 b$ & $32.38 b$ & $41.66 b$ & $42.67 a$ & $105.02 b$ & $76.05 b$ \\
\hline 0.6 & $136.98 a$ & $127.23 a$ & $41.55 a$ & $39.27 a$ & $45.00 \mathrm{a}$ & $43.5 a$ & $109.52 a$ & $88.85 a$ \\
\hline \multicolumn{9}{|l|}{ Inter action (I x H) } \\
\hline 0.00 (Cont.) & $95.90 \mathrm{~cd}$ & $96.07 c$ & $32.33 e$ & $29.47 \mathrm{c}$ & $37.66 \mathrm{~cd}$ & $39.67 e$ & $93.13 \mathrm{~cd}$ & $64.17 \mathrm{c}$ \\
\hline $\begin{array}{c}4 \\
\text { days }\end{array}$ & $102.33 c$ & $109.7 b$ & $33.33 e$ & $38.33 b$ & $42.33 b c$ & $42.66 \mathrm{bc}$ & $100.37 b$ & $82.30 b$ \\
\hline 0.4 & $125.13 b$ & $121.23 b$ & $40.27 b$ & $39.20 \mathrm{ab}$ & $43.66 \mathrm{~b}$ & 44.00ab & $119.87 a$ & $83.17 b$ \\
\hline 0.6 & $140.7 a$ & $136.53 a$ & $44.53 a$ & $41.27 a$ & $48.66 a$ & $44.33 a$ & $123.30 \mathrm{a}$ & $100.26 a$ \\
\hline 0.00 (Cont.) & $55.83 f$ & $39.67 f$ & $19.73 \mathrm{~g}$ & $17.27 \mathrm{e}$ & $35.33 d$ & $37.00 f$ & $85.27 e$ & $55.13 d$ \\
\hline $\begin{array}{c}8 \\
\text { days }\end{array}$ & $70.07 e$ & $59.33 e$ & $25.40 f$ & $19.00 \mathrm{e}$ & $38.67 \mathrm{~cd}$ & 40.33de & 88.83de & $64.97 \mathrm{c}$ \\
\hline 0.4 & $93.03 d$ & $79.40 d$ & $35.10 \mathrm{~d}$ & $25.57 b$ & $39.67 \mathrm{bcd}$ & $41.33 \mathrm{~cd}$ & $90.17 \mathrm{cde}$ & $68.93 c$ \\
\hline 0.6 & $133.27 a b$ & $117.93 b$ & $38.57 \mathrm{c}$ & $37.27 b$ & $41.33 b c$ & $42.67 \mathrm{bc}$ & 95.73bc & $77.43 b$ \\
\hline
\end{tabular}

Means within a column having the same letters are not significantly differences according to Duncan's multiple range test (DMRT).

With regard to the interaction between irrigation intervals and hydrogel rates the results show that the highest values of growth parameters were recorded for seedlings irrigated every 4days and grown in sandy-amended soil with $0.6 \%$ hydrogel for both seasons.

\section{b. Shoot fresh and dry weight, root length and total green color (SPAD)}

The peak values of the previously listed growth parameters were achieved at a 2-day irrigation interval, whereas the minimum values were attained by seedlings subjected to deficit irrigation (irrigation every 8 days) in both seasons (Table, 5). These results are in agreement with those of Afsharmanesh, (2009) and Kamal and El-Shazly (2013).

For hydrogel treatments (Table, 5), the results showed that, soil application of $0.6 \% \mathrm{~g} / \mathrm{g}$ hydrogel gave the higher values of the growth parameters than the other hydrogel rates, compared with the least 
growth parameters obtained with control. Hydrogel had a beneficial impact on the aspects of vegetative growth owing to the implementation of hydrogel at distinct concentrations, the rooting medium can absorb and store large amounts of water during both irrigation periods and then gradually release water when required (Shi et al., 2010). This hydrogel characteristic helps to improve the root development and thus the entire plant growth traits. Similar results were noticed by Arbona et al., (2015) on young citrus plants Chirino et al., (2011) on Cork oak plants.

There was a significant interaction between irrigation periods and hydrogel rates on the vegetative aspects (Table, 5 ). Under irrigation every 4 days and hydrogel concentration ( 0.4 or $0.6 \%$ ) the growth values were pronouncedly higher than those irrigated every 8 days without hydrogel (deficit irrigation treatment).

\section{2-Nutritional status:}

\section{Leaf mineral and proline content:}

Table (6) displayed that leaf $N, P$ and $K$ responded specifically to irrigation intervals. Hence, irrigated seedlings every 4 days had statistically the highest mineral $(\%)$ in leaves, while the reverse was true with those watered every 8 days (watering regime). The positive effects of irrigation every 4 days on mineral uptake could be due to its enhancing effect on transport of dissolved nutrients by mass flow also, the suitable balance of moisture in plant creates favorable conditions for photosynthesis and metabolites translocation, which accelerate the rate of nutrients uptake. On the other hand, the uptake of nutrients was retarded under irrigation deficit circumstances and this may be due to reducing active rooting. Analogous noting has been reported Mostafa (2017) on Conocarpus erectus L. plants, who found that irrigation transplants every 2 days gave the highest $N, P$ and $K(\%)$ in leaves, while irrigation every 4 days gave the lowest values .In the same line, Zoghdan, and Abo EIEnien(2019) on Citrus trees found that the percentage of mineral nutrition in the leaves were decreased under deficit irrigation treatments. Adding the hydrogel polymer at rate 0.6 or $0.4 \%(\mathrm{~g} / \mathrm{g})$ was the best treatment for increasing leaf $\mathrm{N}, \mathrm{P}$ and $\mathrm{K}$ content compared to the control. According to the previous results, it could be concluded that application of hydrogel enhances leaf mineral contents because hydrogel enables absorbing and retaining considerable amount of water and nutrients that would be slowly released into tree roots. This may be due to the increase in the nutrient use efficiency of soil treated with treatments and improving in physio-chemical conditions of soil and affecting the trees response to mitigate drought (Buchholz and Graham, 1998). These results are in harmony with those reported by Anupama et al., (2007), Chirino et al., (2011), Kamran and Chamheidar (2014) on Pyracantha coccinea plants. With regard to, the effect of interaction (irrigation intervals $x$ hydrogel rates), data of both seasons showed that, irrigation every 4 days treatment combined with the highest rates of hydrogel $(0.6 \%)$ resulted the highest values of leaf mineral content.

Irrigation intervals treatments showed significant variations in leaf proline content. The highest values in this respect $(0.47$ and $0.46 \mu \mathrm{mole} / \mathrm{g} \mathrm{fw})$ were recorded with deficit irrigation treatment (irrigation every 8 days), but the lowest values ( 0.35 and $0.35 \mu \mathrm{mole} / \mathrm{g} \mathrm{fw}$ ) were recorded under irrigation interval every 4 days in both seasons, respectively (Table, 6). These results negatively exposed the correlation between 
irrigation rates and proline content as this means that under water stress the hydrolysis of proteins increases which increases accumulation of proline content in the leaves. Leaf proline content was increased with decreasing hydrogel rates from 0.0 up to $0.6 \%$. The highest values in this respect were recorded by the control $(0.0 \%)$ meanwhile the least values were obtained with the high rates $(0.6 \% \mathrm{~g} / \mathrm{g})$ in both seasons.
The maximum and minimum values of leaf proline content belonged to the combined treatment of irrigation every 8 days $x$ hydrogel at $0.0 \%$ and irrigation every 4 days $x$ hydrogel at $0.6 \%$, respectively. In the same line, Ennab and El-Sayed (2014) and Abo El-Enien et al., (2019) stated that proline content in the leaves was increased under deficit irrigation conditions.

Table (6): Effect of irrigation intervals, hydrogel rates and their interaction on leaf mineral and proline contents of Conocarpus erectus L. plants in 2017 and 2018 seasons.

\begin{tabular}{|c|c|c|c|c|c|c|c|c|}
\hline \multirow[t]{2}{*}{ Treatments } & \multicolumn{2}{|c|}{ N (\%) } & \multicolumn{2}{|c|}{$\mathbf{P}(\%)$} & \multicolumn{2}{|c|}{ K (\%) } & \multicolumn{2}{|c|}{$\begin{array}{c}\text { Proline } \\
(\mu \mathrm{mole} / \mathrm{gFW})\end{array}$} \\
\hline & 2017 & 2018 & 2017 & 2018 & 2017 & 2018 & 2017 & 2018 \\
\hline \multicolumn{9}{|l|}{ Irrigation intervals } \\
\hline 4 days & $1.80 \mathrm{a}$ & $1.74 \mathrm{a}$ & $0.35 a$ & $0.33 a$ & $1.41 \mathrm{a}$ & $1.42 \mathrm{a}$ & $0.35 b$ & $0.35 b$ \\
\hline 8 days & $1.62 b$ & $1.52 b$ & $0.24 b$ & $0.23 b$ & $1.33 b$ & $1.32 b$ & $0.47 a$ & $0.46 a$ \\
\hline \multicolumn{9}{|l|}{ Hydrogel rates (\%) } \\
\hline 0.00 (Cont.) & $1.50 \mathrm{~d}$ & $1.50 \mathrm{c}$ & $0.26 \mathrm{~d}$ & $0.25 d$ & $1.35 c$ & $1.35 \mathrm{c}$ & $0.46 a$ & $0.45 a$ \\
\hline 0.2 & $1.60 \mathrm{c}$ & $1.53 \mathrm{c}$ & $0.29 c$ & $0.26 c$ & $1.36 \mathrm{bc}$ & $1.36 c$ & $0.43 b$ & $0.42 b$ \\
\hline 0.4 & $1.82 b$ & $1.68 b$ & $0.30 \mathrm{~b}$ & $0.30 \mathrm{~b}$ & $1.37 \mathrm{~b}$ & $1.37 b$ & $0.39 c$ & $0.39 c$ \\
\hline 0.6 & $1.93 a$ & $1.80 \mathrm{a}$ & $0.34 a$ & $0.32 a$ & $1.40 \mathrm{a}$ & $1.41 \mathrm{a}$ & $0.36 d$ & $0.35 d$ \\
\hline \multicolumn{9}{|l|}{ Inter action (I x H) } \\
\hline 0.00 (Cont.) & $1.58 \mathrm{de}$ & $1.59 \mathrm{de}$ & $0.31 d$ & $0.29 d$ & $1.39 b$ & $1.39 \mathrm{c}$ & $0.41 d$ & $0.39 d$ \\
\hline $\begin{array}{c}4 \\
\text { davs }\end{array}$ & $1.67 \mathrm{cde}$ & $1.61 \mathrm{~d}$ & $0.34 c$ & $0.31 \mathrm{c}$ & $1.40 \mathrm{~b}$ & $1.40 \mathrm{bc}$ & $0.38 \mathrm{e}$ & $0.38 \mathrm{e}$ \\
\hline 0.4 & $1.90 \mathrm{~b}$ & $1.83 b$ & $0.35 b$ & $0.35 b$ & $1.41 \mathrm{ab}$ & $1.42 b$ & $0.33 f$ & $0.33 f$ \\
\hline 0.6 & $2.06 a$ & $1.91 \mathrm{a}$ & $0.40 a$ & $0.38 a$ & $1.43 a$ & $1.47 a$ & $0.30 \mathrm{~g}$ & $0.30 \mathrm{~g}$ \\
\hline 0.00 (Cont.) & $1.42 f$ & $1.40 f$ & $0.20 \mathrm{~h}$ & $0.21 \mathrm{~g}$ & $1.30 \mathrm{e}$ & $1.30 f$ & $0.51 a$ & $0.50 a$ \\
\hline $\begin{array}{c}8 \\
\text { davs }\end{array}$ & $1.53 \mathrm{ef}$ & $1.45 f$ & $0.23 \mathrm{~g}$ & $0.22 \mathrm{~g}$ & $1.32 \mathrm{de}$ & $1.31 \mathrm{ef}$ & $0.48 b$ & $0.47 b$ \\
\hline 0.4 & $1.73 \mathrm{~cd}$ & $1.53 e$ & $0.25 f$ & $0.24 f$ & $1.33 d$ & $1.32 \mathrm{e}$ & $0.46 c$ & $0.45 c$ \\
\hline 0.6 & $1.81 \mathrm{bc}$ & $1.70 \mathrm{c}$ & $0.29 e$ & $0.27 e$ & $1.36 c$ & $1.35 d$ & $0.42 d$ & $0.40 d$ \\
\hline
\end{tabular}

Means within a column having the same letters are not significantly differences according to Duncan's multiple range test (DMRT). 


\section{3-Water relation:}

Results presented in Table (7) revealed that, total and free water contents in leaf tissues were markedly increased by decreasing irrigation periods from 8 up to 4 days. Deficit irrigation treatment (irrigation every 8 days) recorded the signeficantly least values in 2017and 2018 seasons. The decrease in the total and free water content under deficit irrigation (irrigation every 8 days) could be resulted from the reduction of water absorption by the roots. In contrast, the highest values of bound water content and osmotic pressure were recorded with the lower irrigation rate (irrigation every 8 days). These results are in partial agreement with teh findings obtained by Helalya et al., (2017) and Abo El-Enien et al., (2019) on fruit trees. They found that, total and free water contents in leaf tissues were significantly decreased while bound water content and osmotic pressure were increased with deficit irrigation.

Table (7): Effect of irrigation intervals, hydrogel rates and their interaction on some water relation parameters in leaves of Conocarpus erectus L. plants in 2017 and 2018 seasons.

\begin{tabular}{|c|c|c|c|c|c|c|c|c|}
\hline \multirow[t]{2}{*}{ Treatment } & \multicolumn{2}{|c|}{$\begin{array}{l}\text { Total water } \\
\text { content (\%) }\end{array}$} & \multicolumn{2}{|c|}{$\begin{array}{l}\text { Free water } \\
\text { content }(\%)\end{array}$} & \multicolumn{2}{|c|}{$\begin{array}{l}\text { Bound water } \\
\text { content(\%) }\end{array}$} & \multicolumn{2}{|c|}{$\begin{array}{c}\text { Osmotic } \\
\text { pressure(atm) }\end{array}$} \\
\hline & 2017 & 2018 & 2017 & 2018 & 2017 & 2018 & 2017 & 2018 \\
\hline
\end{tabular}

Irrigation intervals

$\begin{array}{lllllllll}4 \text { days } & 60.37 \mathrm{a} & 61.18 \mathrm{a} & 45.62 \mathrm{a} & 44.37 \mathrm{a} & 14.76 \mathrm{~b} & 16.82 \mathrm{~b} & 15.42 \mathrm{~b} & 14.82 \mathrm{~b} \\ 8 \text { days } & 51.73 \mathrm{~b} & 52.80 \mathrm{~b} & 34.73 \mathrm{~b} & 33.29 \mathrm{~b} & 17.01 \mathrm{a} & 19.52 \mathrm{a} & 17.52 \mathrm{a} & 17.37 \mathrm{a}\end{array}$

Hydrogel rates (\%)

$\begin{array}{ccccccccc}0.00 \text { (Cont.) } & 53.22 \mathrm{~d} & 54.20 \mathrm{~d} & 37.18 \mathrm{~d} & 35.35 \mathrm{~d} & 16.60 \mathrm{a} & 18.53 \mathrm{a} & 17.62 \mathrm{a} & 17.50 \mathrm{a} \\ 0.2 & 54.73 \mathrm{c} & 56.06 \mathrm{c} & 39.52 \mathrm{c} & 37.53 \mathrm{c} & 15.67 \mathrm{bc} & 18.85 \mathrm{a} & 17.87 \mathrm{a} & 16.52 \mathrm{~b} \\ 0.4 & 56.42 \mathrm{~b} & 57.30 \mathrm{~b} & 40.75 \mathrm{~b} & 39.58 \mathrm{~b} & 15.22 \mathrm{c} & 17.60 \mathrm{~b} & 15.95 \mathrm{~b} & 15.63 \mathrm{c} \\ 0.6 & 59.83 \mathrm{a} & 60.42 \mathrm{a} & 43.25 \mathrm{a} & 42.87 \mathrm{a} & 16.05 \mathrm{ab} & 17.72 \mathrm{~b} & 14.45 \mathrm{c} & 14.73 \mathrm{~d}\end{array}$

Inter action (I x H)

\begin{tabular}{|c|c|c|c|c|c|c|c|c|c|}
\hline \multirow{3}{*}{$\begin{array}{c}4 \\
\text { days }\end{array}$} & 0.00 (Cont.) & $56.43 d$ & $58.07 d$ & 43.17d & $40.13 d$ & $17.03 b$ & $16.17 d$ & $12.60 f$ & $13.13 f$ \\
\hline & 0.2 & $58.83 \mathrm{c}$ & $59.76 c$ & $44.80 \mathrm{c}$ & 43.07c & $14.67 \mathrm{c}$ & $16.50 \mathrm{~d}$ & $14.87 e$ & $14.00 \mathrm{e}$ \\
\hline & 0.4 & $60.83 b$ & $61.57 b$ & $46.17 b$ & $45.07 \mathrm{~b}$ & $14.03 \mathrm{~cd}$ & $19.03 b$ & $17.23 \mathrm{bc}$ & $15.13 d$ \\
\hline \multirow{5}{*}{$\begin{array}{c}8 \\
\text { days }\end{array}$} & 0.6 & $65.37 a$ & $65.33 a$ & $48.33 a$ & $49.23 a$ & $16.67 b$ & $17.93 \mathrm{c}$ & $17.00 \mathrm{~cd}$ & $17.00 \mathrm{~b}$ \\
\hline & 0.00 (Cont.) & $50.63 \mathrm{~g}$ & $50.33 \mathrm{~g}$ & $31.20 \mathrm{~h}$ & $30.57 \mathrm{~h}$ & $18.80 a$ & $20.37 a$ & $18.73 a$ & $17.90 \mathrm{a}$ \\
\hline & 0.2 & $50.00 \mathrm{~g}$ & $53.03 f$ & $35.33 f$ & $32.00 \mathrm{~g}$ & $16.17 b$ & 19.77ab & $18.00 \mathrm{ab}$ & $18.00 a$ \\
\hline & 0.4 & $52.00 f$ & $52.35 f$ & $34.23 \mathrm{~g}$ & $34.10 f$ & $16.40 \mathrm{~b}$ & $18.93 b$ & $17.03 \mathrm{~cd}$ & $16.33 c$ \\
\hline & 0.6 & $54.30 \mathrm{e}$ & $55.50 \mathrm{e}$ & $38.17 \mathrm{e}$ & $36.50 \mathrm{e}$ & $13.30 \mathrm{~d}$ & $16.70 \mathrm{~d}$ & $16.30 \mathrm{~d}$ & $17.26 b$ \\
\hline
\end{tabular}

Means within a column having the same letters are not significantly differences according to Duncan's multiple range test (DMRT). 
Total and free water contents in leaf tissues were increased with increasing the rates of hydrogel, and the greatest values were obtained with hydrogel at $0.6 \%$ comparing with the lowest values recorded with control (hydrogel at rate $0.0 \%$ ). On the contrary, hydrogel at 0.0 and $0.2 \%$ raised bound water content and osmotic pressure compared with the other rates of hydrogel in both 2017 and 2018 seasons. Improving relative water content under water saving substances treatments may be due to maintaining enough available water for trees to overcome drought stress injuries. In this line, Fernando et al., (2013) found that, hydrogel amendment significantly increased the plant available water (PAW) in sandy soil compared to the control. Also, Arbona et al., (2015) and Barki et al., (2018) found that, hydrogel treatment enhance the capacity to avoid drought damages of trees and improve leaf relative water content.

The interaction between irrigation intervals and hydrogel applications was significant in both seasons. The highest values of total and free water contents in leaf tissues belonged to irrigation every 4 days $x$ hydrogel at $0.6 \%$ combination treatment comparing with the lowest values achieved by irrigation every 8 days $x$ hydrogel at $0.0 \%$.Conversely, the highest values of bound water content and osmotic pressure were achieved by irrigation every 8 days $x$ hydrogel at $0.0 \%$ in both seasons.

\section{4- Soil properties}

\section{Soil moisture characteristic}

Results illustrated in Figures $(1,2$ and 3) indicate the impact of combining irrigation intervals with hydrogel rates on the characteristic soil moisture during the 2017 and 2018 seasons. Generally, all measured soil moisture characteristics were favorably impacted by irrigation periods and rates of hydrogel compared to soil control. Increasing the irrigation intervals from 4 to 8 significantly increased the soil FC (17.10 and $16.50 \%)$ and WP (6.90 and 6.00\%) and decreased the AW (10.20 and $10.40 \%)$, respectively for the first and second seasons. Soil amended with high rate of hydrogel, were able to store much more water than those amended with low rates (the control). The FC, WP, and AW of pots amended with $0.6 \%$ hydrogel were increased compared to the lowest values recorded with control $(0.0 \%$ hydrogel). The interaction of irrigation every 8 days and hydrogel rate at $0.6 \%$ presented the highest FC and WP values in both seasons (25.3 and $8.8 \%$ in the first season and 25.7 and 9.0 in the second one, respectively ) while, the highest AW was presented from the irrigation intervals every 4 days and hydrogel rate at $0.6 \%$ during the two seasons. The alteration of sandy soil physical properties indicates that adding hydrogel, even at small levels, to the soil increases the period of time at which the soil remains moistned than the control soil. This allows the irrigated water not to be wasted after irrigation, but stored in the soil and released under the mechanism controlled by plant roots absorption and evaporation (Al-Humaid and Moftah, 2007 and Sannino, 2008). In addition, the application of the amendment also encouraged formation of soil aggregates that, in turn, decreased the soil bulk densities. The results submitted are in line with the findings of Koupai et al., (2008), Bhat et al., (2009) and El-Kady and Borham (2013), who recorded the positive effect of absorbent polymers on soil density, compactness, texture, aeration, water retention and available water. 


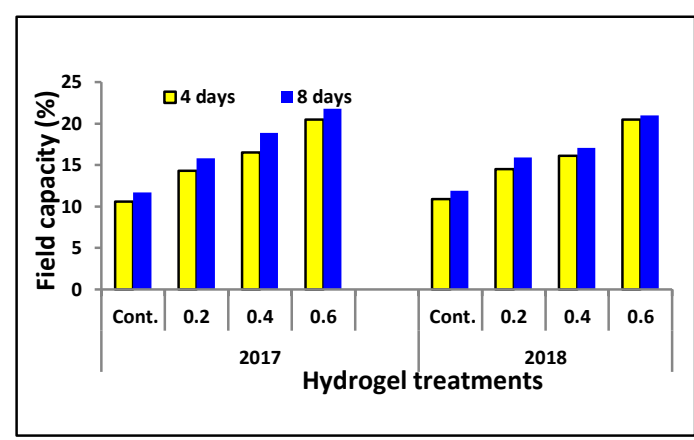

A

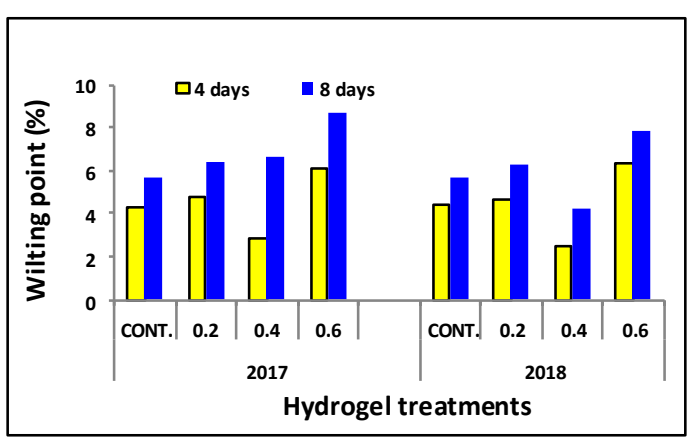

B

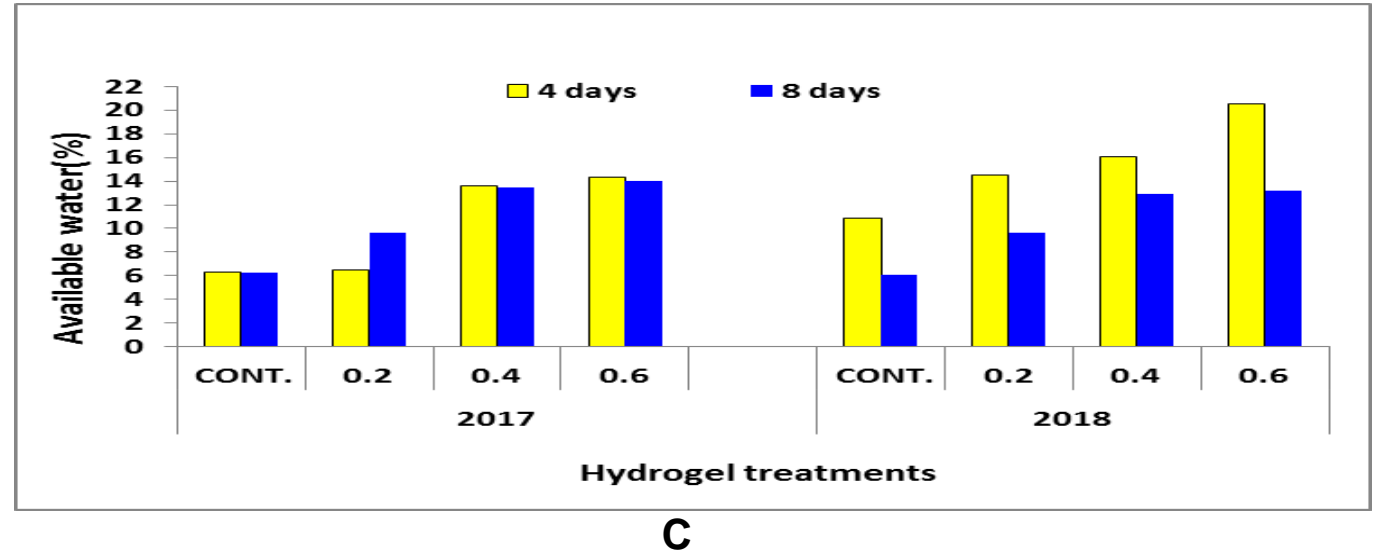

Fig. 1: Effect of irrigation intervals, hydrogel rates and their interaction on some soil properties, (A) field capacity (B)wilting point (C) available water during 2017 and 2018 seasons.

\section{CONCLUSION}

Based on the results obtained from this study, it is recommended to add 0.4 or $0.6 \%(\mathrm{~g} / \mathrm{g})$ hydrogel polymer amended sandy soil for the establishment of Conocarpus erectus plants under the two irrigation intervals (every 4 and 8 days) which is considered the best treatment in the ability to improve the growth parameters, and rationalize the amount of irrigation water in sandy soil under the experimental conditions.

\section{REFERENCES}

Abo El-Enien, M.M.S., E.A. Moursi and W. M. El-Rouby (2019). Effect of some drip irrigation and nano-silicon treatments on growth, yield and water relations of "Washington Navel" orange trees grown in new reclaimed soils. J. Plant
Production, Mansoura Univ., 10 (7): 529 $-537$.

Afsharmanesh, G. (2009). Study of some morphological traits and selection of drought resistant alfalfa cultivars (Medicago sativa L.) in Jiroft, Iran. Plant Ecophysiology, 3: 109-118.

Al-Humaid, A.I. and A.E. Moftah (2007). Effects of hydrophilic polymer on the survival of buttonwood seedlings grown under drought stress. Journal of Plant Nutrition, 30: 53-66.

Andry, H., T. Yamamoto, T. Irie, S. Moritani, $M$. Inoue and $H$. Fujiyama (2009). Water retention, hydraulic conductivity of hydrophilic polymers in sandy soil as affected by temperature and water quality. Journal of Hydrology, 373: 177-183. 
Anupama, M.C., R. Kumar and B.S. Parmar (2007). Performance of a new superabsorbent polymer on seedling and post planting growth and water use pattern of chrysanthemum grown under controlled environment. Acta Hort., 742, ISHS 2007.

Arbona, V., D. J. Iglesias, J. Jacas, E. Primo-Millo, M. Talon and A. Cadenas (2015). Hydrogel substrate amendment alleviates drought effects on young citrus plants. Plant and Soil, 270: 7382.

Atkinson, C.J., A.D. Webster, S.P. Vaughan, L. Taylor and G. Kingswell (2000). Interaction between root restriction, irrigation rootstock treatments on "Queen Cox" apple trees: Effect of soil and plant water relation. J. Hort. Biotech., 75(4): 376382.

Barki, N., H. Chehab, F. Aissaoui, O. Dabbaghi, F. Attia, Z. Mahjoub, S. Laamari, B. Chihaoui, T. Giudice, A. Jemai, D. Boujnah and B. Mechri (2018). Effects of mycorrhizal fungi inoculation and soil amendments with hydrogel on leaf anatomy, growth and physiology performance of olive plantlets under two contrasting water regime. Acta Physiologiae Plantarum 40, 116-126.

Bates, L.S., R.P. Waldren and L.D. Teare (1973). Rapid determination of free proline for water stress studies. Plant and Soil, 39: 205-207.

Bhat, N.R., M. K. Suleiman, H. Al-Menaie, E. H. Al-Ali, L.AL-Mulla, A. Christopher, V.S Lekha, S.I. Ali and P. George (2009). Polyacrylamide polymer and salinity effects on water requirement of Conocarpus lancifolius and selected properties of sandy loam soil. European Journal of Scientific Research 25: 549-558.
Black, C. A. (1965). Methods of Soil Analysis. Part I and II. Am. Soc. Agron. Inc. Pub. Madison, Wisconsin, U.S.A.

Bricker, B. (1991). MSTATC: A Micro Computer Program from the Design Management and Analysis of Agronomic Research Experiments. Michigan State

Buchholz, F.L. and A.T. Graham (1998). In "Modern Superabsorbent Polymer Technology", Wiley, V.C.H. (ed.), New York, NY (USA). ISBN: 0-471-19411-5.

Chapman, H.D. and P.F. Pratt (1978). Methods of Analysis for Soils, Plant and Water. Univ. California USA.

Chirino, E., A. Vilagrosa and V. Ramón Vallejo (2011). Using hydrogel and clay to improve the water status of seedlings for dry land restoration. Plant Soil,344:99-110

Duncan, B.D. (1955). Multiple range and multiple F-test . Biometrics, J. 11:1-42.

El-Kady, A. F.Y. and T. I. Borham (2013). Improving some physical properties of sandy soil and Conocarpus erectus $\mathrm{L}$. plant growth. Egypt. J. Soil Sci., 53 ( 4):595-611.

Ennab, H.A. and S.A. El-Sayed (2014). Response of Balady mandarin trees to deficit irrigation. J. Agric. Res. Kafrelsheikh Univ., 40(3): 616-629.

Esteban, C., V. Alberto and V. Ramón Vallejo (2011). Using hydrogel and clay to improve the water status of seedlings for dry land restoration. Plant Soil, 344:99-110

Fernando, T.N., A.G.B. Aruggo, C. K. Disanayaka and S. Kulathunge (2013). Effect of super water absorbent polymer and watering capacity on growth of tomato (Lycopersicon esculentum Mill) Journal of Engineering and Technology of the Open University of Sri Lanka (JETOUSL), 1(2):1-14. 
Ghasemi, M. and M. Khoshkhoe (2007). Effect of superabsorbent polymers on irrigation interval and growth and development of Chrysanthemum morifoliumramat. J. of Horticultural Science and Technology, 8(2): 65-82.

Hassan, H., A. Hosseini, I. Nosratti and M. Khoramivafa (2017). Effect of watersuperabsorbent and drought on seedling establishment and growth in some warm season plants. Agriculture Science and Practice, 3 (4): 5-11.

Hegazy, S.S., I. M. Aref, H. Al-Mefarrej and L.I. El-Juhany (2008). Effect of spacing on the biomass production and allocation in Conocarpus erectus L. trees grown in Riyadh, Saudi Arabia. Saudi Journal of Biological Sciences, 15: 315-322.

Helalya, M. N., H. El-Hoseinyb, N. I. ElSheeryc, A. Rastogid and H. M. Kalajif (2017). Regulation and physiological role of silicon in alleviating drought stress of mango. Plant Physiology and Biochemistry Xxx: 2-14.

Hüttermann, A., M. Zommorodi and K. Reise (1999). Addition of hydrogels to soil for prolonging the survival of Pinus halepensis seedlings subjected to drought. Soil Tillage Res., 50:295-304

Jackson, M.L. (1967). Soil Chemical and Plant Analysis. Prentice Hall of India, New Delhi.

Kamal, A. M. and M. M. El-Shazly (2013). Maximizing the productivity and water use efficiency of tomato plants (Fycopersicon esculentum Mill.) cultivated in the new reclaimed lands using different irrigation water quantities and some water saving substances. J. Plant Production, Mansoura Univ., 4 (9): 1399 - 1416.

Kamran, P. and H. Chamheidar (2014). Improving moisture in the rooting media of Pyracantha coccinea cuttings by using super absorbent hydrogel.
Bull. Env. Pharmacol. Life Sci., 3 (10): 119-125.

Kargar, M., R. Suresh, M. Legrand, P. Jutras, O. Grant Clark and O. Prasher (2017). Reduction in water stress for tree saplings using hydrogels in soil. Journal of Geoscience and Environment Protection, 5: 27-39.

Klute, A. (1986). Methods of Soil Analysis. part 1. Physical and Mineralogical Methods", $2^{\text {nd }}$ ed., American Society of Agronomy-Soil Science Society of America, Madison, Wisconsin, USA.

Koshnirinko, M.D., A.A.A. Gonsharova and E.M. Bonder (1970). Methods of Study Water Relation and Drought Resistance of Fruit Trees. Acad. Sci. Press, Maldovia, USSR, pp. 53-61.

Koupai, A.J., S.S. Eslamian and J.A. Kazemi (2008) Enhancing the available water content in unsaturated soil zone using hydrogel, to improve plant growth indices. Ecohydrology and Hydrobiology 8: 67-75.

Mostafa, H. G. (2017). Response of Conocarpus erectus $\mathrm{L}$. plants to different irrigation intervals and cytokinin spray application. Ph. D. Thesis, Faculty of Agriculture Cairo University, Egypt, 110 pp.

Mpelasoka, B.S., M.H. Behboudian and T.M. Mills (2001). Water relations, photosynthesis, growth, yield and fruit size of "Braeburn" apple: response to deficit irrigation and to crop load. J. Hort. Sci. and Biotechnology, 76(2): 150-156.

Murphy, J. and J.D. Riely (1962). A modified single solution method for the determination of phosphate in natural water. Anal. Chem. Acta, 27: 31-36.

Orikiriza, L.J.B., H. Agaba, M. Tweheyo, G. Eilu, J.D. Kabasa and A. Huttermann (2009). Amending soils with hydrogels increases the biomass of nine tree 
species under non-water stress conditions. Clean, 37: 615-620.

Sannino, A. (2008). Application of superabsorbent hydrogels for the optimization of water resources in agriculture. The $3^{\text {rd }}$ International Conference on Water Resources and Arid Environments and the $1^{\text {st }}$ Arab Water Forum.

Sheikh, F., A. Arji, A. Esmaeeli and A. Abdousi (2010). Study of the effect of irrigation interval and superabsorbent polymer on some qualitative properties of sports turf. J. Hort. Sci., 25(2): 170177.

Shi, Y., J. Li., J. Shao, S. Deng, R. Wang, N. $\mathrm{Li}, \mathrm{A}$. Huttermann and A. Chen (2010). Effects of stockosorb and luquasorb polymers on salt and drought tolerance of Populus popularis. Scientia Horticulturae, 124: 268-273.
Snedecor, G.W. and W.G. Cochran (1990). Statistical Methods. 7th Ed. Iowa State Univ. Press. Ames., lowa, USA., 593 p.

Yadava, U.L. (1986). A rapid and nondestructive method to determine chlorophyll in intact leaves. HortScience 21:1449-1450

Yazdani, F., I. Allahdadi and G.A. Akbari (2007). Impact of superabsorbent polymer on yield and growth analysis of soybean (Glycine max L.) under drought stress condition. Pakistan J. of Biolog. Sci., 10 (23): 4190-4196.

Zoghdan, M. G. and M. M. S. Abo El-Enien (2019). irrigation regime and soil conditioners impact on characteristics of sandy soil and Washington Navel orange trees J. Soil Sci. and Agric. Eng., Mansoura Univ., 10 (4): 233 - 243. 
استجابة نباتات الكونوكاريس النامية في التربة الرملية للمعاملة بالهيدروجيل تحت ظروف التقص المائي

(2)

محمد السيد عبد الجيد(1)، السيد ابو الفتوح مرسىى)

(1) قسم بحوث الحدائق النباتية -معهر بحوث البساتين-مركز البحوث الزراعية-الجيزة سمصر

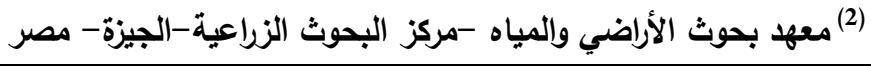

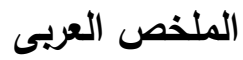

يُعد نقص مياه الري من أحد العوامل الرئيسية التي تحد من نمو النباتات وخاصة في المناطق الجافة وشبه الجافة لذلك أجريت هذه الدراسة لتقييم تأثير اضافة الهيلروجيل بوليمر لتقليل الآثار السلبية الناتجة عن نقص مياه الرى، حيث التئ تم اجراء تجرية اصص خلال عامي 2017 و 2018 بالمزرعة البحثية محطة بحوث البساتين بسخا- معهد بحوث

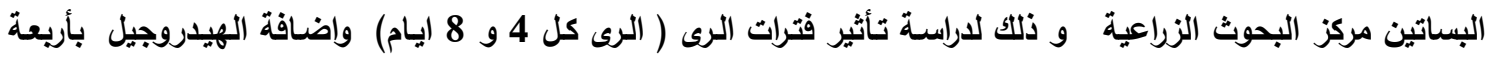

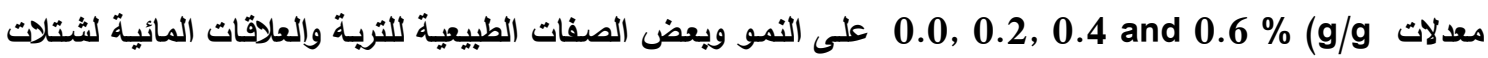
الكونوكاريس المنزرعة في تربة رملية.

أوضحت النتائج التي تم الحصول عليها ان هناك زيادة معنوية فى قياسـات النمو الخضرى (ارتفاع النبات وعدد

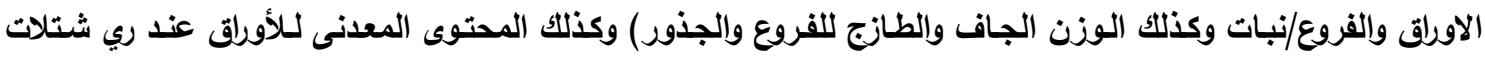

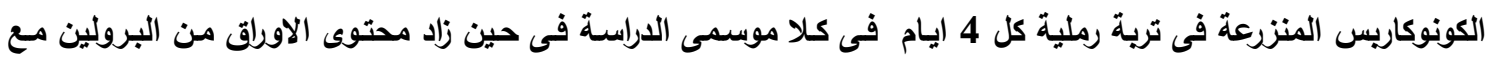
الرى كل 8 ايام

سجلت الاراسة زيادة معنوية فى معظم قياسات النمو الخضرى ومحتوى الاولق من الغناصر عند اضافة الهيدروجيل بمعدل 0.4 او \% 0.6 ، حسنت معاملات الرى كل 4 او 8 ايام والمعدل العالي من الهيدروجيل والتداخل بينهم من التهائ خصائص الصفات الطبيعية للتربة (السعة الحقلية والماء الميسر) وكنلك سجلت اعلى القيم للماء الكلى والمرتبط للأورلق. وفقًا للنتائج التي تم الحصول عليها في ظل ظروف الدراسة ، يمكن التوصية بإطالة فترات الرى لثتتلات الكونوكاريس المنزرعة في التربة الرملية من 4الى 8 ايام مع اضافة الهيدروجيل بمعل 0.4 او \% 0.6 مما يؤدى إلى تحسين النمو الخضري ، بجانب زيادة كفاءة استخدام المياه مع توفير مياه الري عن طريق تقليل كمية المياه المضافة مقارنة بالري بدون اضافة الهيدرجيل. 


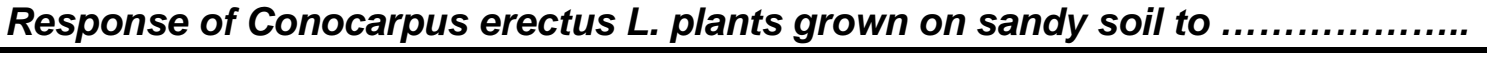

